\title{
Detection, Distribution, Sporulation, and Survival of Phytophthora ramorum in a California Redwood-Tanoak Forest Soil
}

\author{
E. J. Fichtner, S. C. Lynch, and D. M. Rizzo
}

Department of Plant Pathology, UC Davis, Davis, CA 95616.

Accepted for publication 8 May 2007.

\begin{abstract}
Fichtner, E. J., Lynch, S. C., and Rizzo, D. M. 2007. Detection, distribution, survival, and sporulation of Phytophthora ramorum in a California redwood-tanoak forest soil. Phytopathology 97:1366-1375.

Recovery of Phytophthora ramorum from soils throughout sudden oak death-affected regions of California illustrates that soil may serve as an inoculum reservoir, but the role of soil inoculum in the disease cycle is unknown. This study addresses the efficacy of soil baiting, seasonal pathogen distribution under several epidemiologically important host species, summer survival and chlamydospore production in soil, and the impact of soil drying on pathogen survival. The efficacy of rhododendron leaves and pears as baits for detection of soilborne propagules were

californica), tanoak (Lithocarpus densiflorus), and redwood (Sequoia sempervirens) were determined by monthly baiting. Summer survival and chlamydospore production were assessed in infected rhododendron leaf disks incubated under bay laurel, tanoak, and redwood at either the surface, the litter/soil interface, or in soil. Rhododendron leaf baits were superior to pear baits for sporangia detection, but neither bait detected chlamydospores. Most inoculum was associated with bay laurel and recovery was higher in soil than litter. Soil-incubated inoculum exhibited over $60 \%$ survival at the end of summer and also supported elevated chlamydospore production. $P$. ramorum survives and produces chlamydospores in forest soils over summer, providing a possible inoculum reservoir at the onset of the fall disease cycle.
\end{abstract} compared. Natural inoculum associated with bay laurel (Umbellularia
Over the past decade, Phytophthora ramorum has incited extensive mortality of susceptible oak (Quercus spp.) and tanoak (Lithocarpus densiflorus) in discontinuous patches of coastal forests from Big Sur, California (CA) to southwestern Oregon (OR) $(36,38)$. Though the pathogen has an extensive and expanding host range, the lethal cankers caused by $P$. ramorum on oak and tanoak prompted the term sudden oak death (SOD) for this disease on oaks $(7,37)$. P ramorum also causes Ramorum blight or Ramorum dieback, nonlethal diseases of numerous native hardwood and coniferous forest tree species, understory shrubs, and herbaceous plants $(8,11)$. While $P$. ramorum has already impacted the stand structure of CA forests causing landscape level alterations, it continues to pose a threat to the integrity and biodiversity of native forests in North America (38).

$P$. ramorum was first associated with nursery plants in Europe (46) and was not associated with forest health until the elucidation of its role in SOD (37). Since its initial discovery in CA, $P$. ramorum has been found in southwest OR where the isolated disease incidence incited ongoing eradication efforts $(12,13,23$, 38). Until recently, all European isolates of P. ramorum belonged to the A1 mating type, and all American isolates belonged to the A2 mating type, suggesting that the pathogen was introduced separately to the two continents (20). The alternate mating types have since been found in nursery settings in both continents (14, 45 ), suggesting a role of the nursery industry in pathogen dispersal. Current strategies for prevention of long-distance spread focus on quarantine of nursery plants and plant products (1), while strategies for limiting spread within a landscape or region focus on early detection and inoculum management such as limiting movement of soils and water from infested to uninfested areas (38).

Corresponding author: E. J. Fichtner; E-mail address: ejfichtn@ucdavis.edu

doi:10.1094/PHYTO-97-10-1366

(c) 2007 The American Phytopathological Society
The epidemiology of $P$. ramorum in coastal forests is influenced by CA's Mediterranean climate with characteristic wet and dry seasons $(9,38)$. Similar to the $P$. palmivora pathosystem on cacao (44), sporulation of $P$. ramorum is seasonal and correlated to rain events and warm temperatures $(9,38)$. The disease manifests as nonlethal foliar lesions on bay laurel (Umbellularia californica) which support prolific sporangia production during rain events (9). Furthermore, chlamydospore production has been observed on naturally infected bay leaves (7), but the magnitude of chlamydospore production varies between sites (E. J. Fichtner, unpublished data). Conversely, no sporulation is observed on bleeding cankers on the main stems of oak and tanoak species (9); however, foliage and small twigs of tanoak do support sporulation (39). Emphasizing the role of bay laurel in the epidemiology of sudden oak death, presence of $P$. ramorum is correlated with presence of bay laurel, and foliar infections on bay laurel generally precede the infection of adjacent oaks (36). In addition to the heightened sporulation potential on bay laurel, $P$. ramorum also survives the hot, dry summer months in a proportion of symptomatic leaves (6).

Though many Phytophthora spp. are present or dispersed in soil (10), the role of soilborne inoculum in dissemination and survival of $P$. ramorum is largely unknown. $P$. cactorum and $P$. palmivora are generally considered above-ground pathogens of apple and cocoa, respectively, but both pathogens have been isolated from roots of asymptomatic trees $(18,44)$. Unlike $P$. quercina which is associated exclusively with the roots of oaks (21), symptoms of $P$. ramorum have only been observed in aboveground plant parts with stem lesions ending at the soil line (11, 37). Nevertheless, multiple lines of evidence suggest that $P$. ramorum may have a soil phase. In laboratory experiments, soilborne inoculum of $P$. ramorum has been shown to indirectly infect bay laurel seedlings via intermediate infection of leaf litter and subsequent simulated rain events (9). The pathogen has been isolated from tanoak roots (35), and dieback of tanoak sprouts has been observed following clear cut and burn treatments in the OR eradi- 
cation zone (13). In nursery systems, the pathogen has been isolated from rhododendron roots (2) and infects weeds of common container culture in experimental inoculations (39). P. ramorum can survive in potting media up to 12 months (27), and infested medium has been shown to incite root infections in rhododendron (26). The role of soil inoculum in the disease cycle within CA forests has not been directly addressed.

During the rainy season, $P$. ramorum has been pear-baited from soil under infected oaks in a CA mixed-evergreen forest, but recovery was low (20\%) and undetectable a month after rains ceased $(7,9)$. Lack of summer recovery by baiting suggests that the pathogen is either not viable, or viable but undetectable due to low population density or presence of dormant propagules. In general, Phytophthora spp. quickly lose viability upon drying conditions $(32,41,42,44)$. Further studies are needed to determine the seasonal distribution of $P$. ramorum under host tree species and the relative efficacy of baiting techniques. For example, pears and apples are ineffective for baiting P. quercina, whereas oakleaf baits consistently detect the pathogen in soil (21), and cocoa pod baits are more effective than direct isolation of $P$. palmivora from roots (44).

Because Phytophthora spp. may persist in soil for years in the absence of host tissue $(44,47)$, the survival potential of $P$. ramorum in soil requires investigation. Long-term survival of $P$. cinnamomi is probably due to the formation of chlamydospores and oospores in roots and soil (32), yet in the $P$. ramorum system, production of chlamydospores in soil is unknown. In cocoa plantations, $P$. palmivora survival is inhibited by leaf litter mulch (25); however, preliminary data on $P$. ramorum illustrate higher recovery from the soil layer than the overlying litter layer (7). Given that some Phytophthora spp. may exhibit enhanced survival when buried in soil rather than incubated at or near the soil surface (18), the survival potential of $P$. ramorum should be investigated over a vertical distribution in forest soils.

$P$. ramorum produces abundant chlamydospores in vitro (37, 46 ), but the survival and role of these propagules in the SOD disease cycle are unknown. Chlamydospores are considered more resistant structures than zoospores and sporangia $(15,16)$, but preliminary data on chlamydospores of $P$. ramorum suggest that they are killed by drying at $30 \%$ relative humidity at room temperature for $30 \mathrm{~min}$ (7). Chlamydospores of $P$. ramorum tend to germinate with a sporangiophore carrying a few sporangia, rather than with hypae (46). While production of chlamydospores in soil varies between Phytophthora spp. (30), the production and persistence of $P$. ramorum chlamydospores in soils is unknown.

The overall focus of this work is to elucidate the role of forest soil in summer survival of $P$. ramorum and its ability to serve as a reservoir of inoculum at the onset of the fall rainy season. To achieve this goal, we address these specific objectives: (i) critically assess the efficacy of pear and rhododendron leaf baits at detecting populations of chlamydospores and sporangia in soil, (ii) investigate seasonal distribution of $P$. ramorum in soil and leaf litter under host tree species, (iii) assess the summer survival potential of $P$. ramorum in soils, (iv) determine the potential for chlamydospore production in soil, and (v) elucidate the role of soil drying on pathogen survival and chlamydospore production in mineral and organic forest soils.

\section{MATERIALS AND METHODS}

Study site. Field-based experiments and observations were conducted in a redwood-tanoak forest at Jack London State Park (JLSP) in Sonoma County, CA $\left(122^{\circ} \mathrm{W}, 38^{\circ} \mathrm{N}\right)$. In November 2003, 15 trees each of bay laurel, tanoak, and redwood (Sequoia sempervirens) were tagged for repeated sampling over time. Tagged trees were selected within heavily infested areas, either within or adjacent to field plots established by P. Maloney (28). The total disease incidence within bay laurel, tanoak, and red- wood was approximately 90, 55, and $10 \%$, respectively, at JLSP in 2004 and 2005 (D. M. Rizzo, unpublished data). Individual trees were selected to maximize distance from dissimilar overstory species, thereby minimizing the influence of adjacent species on soil characteristics and input of natural inoculum from neighboring sources. The parent material of the soils is residuum weathered from metavolcanics and the dominant series are Spreckles and Goulding (4). Daily precipitation data were recorded by park staff.

Soil characteristics. Because soil characteristics vary greatly over short spatial distances, measurements of soil $\mathrm{pH}$ and organic matter content were assessed under the 45 tagged trees. Three soil samples were collected within a $1.5 \mathrm{~m}$ radius of each tree, bulked, and mixed thoroughly. The $\mathrm{pH}$ was determined for samples collected monthly from April 2004 through November 2004 in a $1: 2$, wt/vol, suspension in $0.01 \mathrm{M} \mathrm{CaCl}_{2}$ solution (40). The $\mathrm{pH}$ values associated with the three host species over time were analyzed with a repeated measures analysis of variance (ANOVA). Soil samples collected in July 2004 were air dried, sieved, and analyzed for organic matter content using a modified WalkleyBlack method (33) at the ANR Analytical Lab, UC Davis. The soil organic matter contents associated with the three host tree species were distinguished using an ANOVA followed by a Waller-Duncan $K$ ratio test $(K=100)$ to separate means. All statistical analyses were conducted using SAS (SAS Institute, Cary, NC) statistical software.

Bait efficacy. The efficacy of pear fruits and rhododendron leaves to bait sporangia and chlamydospores from soil was determined in the lab using an isolate of $P$. ramorum recovered from soil at JLSP (D. M. Rizzo lab culture collection, UC Davis). To induce sporangia formation, agar plugs were excised from 1week-old colonies of $P$. ramorum grown on $1 / 3$ strength V8 agar and incubated for $48 \mathrm{~h}$ in soil water. Plates were shaken to dislodge sporangia, and the resulting spore suspension was quantified with a hemacytometer. Chlamydospores were harvested from 14-day-old colonies grown in V8 broth by blending $30 \mathrm{~s}$ in a Waring blender. Spores were then collected by passing the suspension through 100 and $50 \mu \mathrm{m}$ nested sieves and resuspending in deionized water. The combined blending and sieving were essential to detach chlamydospores from hyphae and ensure that only chlamydospores were introduced to the system. Chlamydospore concentration was quantified in aliquots under a dissecting microscope.

Uninfested soil (Yolo silty clay loam) was collected from the Armstrong Field Station (Davis, CA), passed through a 2-mm sieve, mixed with coarse sand $(1: 1, \mathrm{vol} / \mathrm{vol})$, and 0.5 liter of the soil/sand mixture was placed into each of 48 freezer bags. To reduce pesticide residue, D'Anjou pears were thoroughly washed prior to use and rhododendron cv. Colonel Coen were not sprayed with fungicides. The two propagule types were each embedded on a $4-\mathrm{cm}^{2}$ segment of fine filter paper by gentle application of negative pressure with an aspirator attached to a Büchner funnel. The application of approximately 30 spores to each segment was confirmed by transferring additional filter paper segments to a selective medium amended with $0.05 \mathrm{~g}$ of hymexazol per liter (PARPH) $(10,29)$ and allowing $24 \mathrm{~h}$ for spore germination. After $24 \mathrm{~h}$, filter papers were removed from agar and the number of propagules adhering to the agar was counted. The spore-embedded segments were either cut and broadcast in soil or placed in intimate contact with bait materials by adhering segments to leaves or fruit with flexible adhesive bandages. When affixing the filter paper segments to the baits, each segment was cut in half and adhered to the bait in two locations. For rhododendron leaf baits, the segments were placed on the abaxial and adaxial leaf surfaces, and for pears, segments were attached to opposing sides of the fruit. Uninfested filter paper segments were utilized as controls and four replicates were established for each treatment. Baits were then partially submerged in supersaturated soil. Baits 
were incubated in soil for 2 days and then rinsed with deionized water. Rhododendron leaves were incubated in moist chambers for an additional 2 days prior to isolation, whereas lesions on pears were sampled immediately due to the onset of fruit rot while in saturated soils. Lesions were sampled from bait materials and submerged in PARPH. Isolation plates were stored 1 week in the dark before determination of percent $P$. ramorum recovery. The experiment was run three times to account for potential differences in pear quality throughout the year. All baiting and inoculum preparation in subsequent studies utilized rhododendron cv. Colonel Coen leaves and the same pathogen isolate.

Seasonal distribution. The distribution of inoculum under the 15 tagged bay laurel, tanoak, and redwood trees was monitored monthly from December 2003 through October 2005. Approximately 0.5 -liter samples of both soil and leaf litter were collected and returned to the lab for baiting. Gravimetric soil moisture content was determined for 10 random samples from each host tree species with five subsamples (approximately $10 \mathrm{~g}$ each) per sample. Samples were weighed and then oven dried at $105^{\circ} \mathrm{C}$ for $48 \mathrm{~h}$ prior to determination of dry weight. P. ramorum was baited from soil and litter with rhododendron leaves according to the aforementioned procedure. Frequency of pathogen recovery and soil moisture content were recorded over time.

Summer pathogen survival. Ten tagged trees each of bay laurel, tanoak, and redwood were selected for assessment of survival in associated soils over the summer of 2004 and 2005. Approximately 4,000 rhododendron leaf disks were cut with a 1- cm-diameter cork borer, puncture wounded, and inoculated with agar slurry of $P$. ramorum. Inoculated leaf disks were incubated in moist chambers for 1 week. The agar was then rinsed off leaf disks, and 10 symptomatic leaf disks were placed in each of 360 mesh sachets. Sachets were stored in moist chambers until dispersal in the field the following day. To assess for initial recovery, 100 leaf disks were submerged in PARPH.

Mesh sachets were deployed to the field on 27 April 2004 and on 24 May 2005, near the end of the spring rainy season. Four points were selected at $1.5-\mathrm{m}$ radii from each tree to allow for destructive sampling over time. Sachets were arranged vertically within partially submerged plastic cylindrical barriers $(17 \mathrm{~cm}$ diameter) to prevent lateral pathogen movement. Soil was disturbed to approximately $8 \mathrm{~cm}$ below the surface. Sachets were arranged at three depths: $6 \mathrm{~cm}$ below the soil surface, the leaf litter/soil interface, and the leaf litter surface. One set of vertical sachets was retrieved at each of four time points: $1,2,8$, and 25 weeks after deployment in 2004, and 1, 2, 8, and 22 weeks in 2005. To determine whether soil serves as an inoculum reservoir at the onset of winter, the 25 week sample time in 2004 was within 1 week after the first fall rain event, and the 22 week sample in 2005 was prior to the first fall rain event.

At each of the four time points, sachets were destructively sampled and leaf disks were then submerged in PARPH. After 3 weeks in selective medium, pathogen recovery was recorded. Based on the observations of Hüberli et al. (19) of enhanced recovery of $P$. cinnamomi after tissue hydration, leaf disks designated as $P$. ramorum-negative were then incubated for 3 weeks in deionized water before being returned to PARPH for subsequent reassessment of recovery. The influence of host tree association, and of vertical location on pathogen recovery over time were assessed using repeated measures ANOVA with between-subject factors and within subject interactions determined using a Wilks' Lambda test.

Soil samples were taken from each tree upon the introduction of inoculum to the field and at each sample time. Samples were taken both inside the cylindrical barrier and directly outside the cylindrical barrier in an effort to detect the potential transfer of the pathogen from the infested leaf tissue to the bulk soil. In the laboratory, gravimetric soil moisture content was assessed using the aforementioned technique and the average soil moisture con- tent associated with each tree was recorded. Soil moisture content associated with tree species over time was assessed with repeated measures ANOVA. Soil samples were then baited for detection of $P$. ramorum. Frequency of bait recovery of the pathogen inside and outside the cylinders was determined for each sample time.

Chlamydospore production. All leaf disks $(n=900)$ from the last sample time were incubated in $1 \mathrm{M} \mathrm{KOH}$ for 3 weeks to render tissue translucent or clear enough to visualize chlamydospores under the light microscope. Five chlamydospore counts were taken under the $\times 10$ field of view $\left(1.6 \mathrm{~mm}^{2}\right)$ and the average number of chlamydospores per field of view was recorded. Observations of chlamydospore germination events were also noted. Chlamydospore count data were recorded in correspondence with three possible pathogen recovery categories: prehydration positive, posthydration positive, or posthydration negative. It is important to note that all prehydration negative disks were hydrated. Utilizing the entire chlamydospore data set, a GLM procedure and Waller-Duncan $K$ ratio test $(K=100)$ were employed to determine the influence of host soil association and vertical location on chlamydospore production. To determine whether differences in pathogen recovery upon initial isolation are related to varying levels of colonization of leaf disks, the chlamydospore populations in prehydration positive and prehydration negative disks were compared using a two-tailed $t$ test. Lastly, sachets having contained both posthydration positive and posthydration negative leaf disks were selected for a paired, two-tailed $t$ test to determine whether hydration-related recovery was linked to chlamydospore populations.

Effect of soil drying. A growth chamber experiment was designed to address the role of soil type and soil drying on survival and chlamydospore production of $P$. ramorum. In September 2005 , approximately 1.1 liter of soil was collected from each of the 10 redwood and bay trees utilized in the field study. Soils associated with each host species were separately bulked and thoroughly mixed before distribution into 48 pots. Soils were then saturated with deionized water and drained to container capacity. Pots were placed into bins containing $2.5 \mathrm{~cm}$ of water, with the distance between the soil surface and the free water surface being $9 \mathrm{~cm}$ or $0.9 \mathrm{kPa}$ matric potential $\left(\Psi_{\mathrm{m}}\right)$. After pots were allowed to equilibrate a few hours, infected leaf disk inoculum was introduced to each pot.

Leaf disk inoculum was produced by the aforementioned methodology and 15 leaf disks were placed into each of 48 sachets and then buried below the soil surface in each pot. Fortyfive leaf disks were plated onto PARPH to determine initial percent pathogen recovery. Upon the introduction of inoculum, soil moisture content was measured in three randomly selected pots each of the redwood and bay laurel soils with five subsamples taken from each pot. Soil samples were specifically sampled from the soil surface to determine moisture content in the vicinity of incubating sachets. After inoculum introduction, pots were placed within a dark growth chamber maintained at $17^{\circ} \mathrm{C}$ and $64 \%$ relative humidity in a completely randomized design. Over the course of 24 weeks, half of the pots were allowed to dry, while the other half was maintained at $0.9 \mathrm{kPa} \Psi_{\mathrm{m}}$.

The treatment design was a complete factorial with two soil types and two moisture regimes. Pathogen recovery was determined over time by destructively sampling three replicates of each treatment after 1, 4, 8, and 24 weeks. Soil moisture and pathogen recovery on PARPH were determined at every time point and chlamydospore production was assessed in disks recovered after 1 week. Effects of soil moisture regime and soil type on pathogen recovery over time were assessed with repeated measures ANOVA with between-subjects factors and differences within subjects assessed with a Wilks' Lambda test. The effects of soil moisture regime and soil type on chlamydospore production were assessed with PROC GLM and differences between 
treatments were determined with a Waller-Duncan $K$ ratio test $(N=100)$. The experiment was run twice.

\section{RESULTS}

Soil characteristics. Soil characteristics varied in association with different host tree species, with redwood-associated soils having higher organic matter content than those associated with either bay laurel or tanoak $(P \leq 0.01)$ (Table 1$)$. The average organic matter content of the organic redwood-associated soils was $>20 \%$, in comparison with the soils associated with bay laurel and tanoak. The $\mathrm{pH}$ range of soils was 5.5 to 6.1 , with those associated with tanoak having a lower $\mathrm{pH}$ than those associated with redwood and bay laurel $(P \leq 0.01)$ (Table 1$)$. The $\mathrm{pH}$ values associated with specific host species did not change significantly over time.

Bait efficacy. Chlamydospores were not detected by use of either rhododendron leaves or pears. Rhododendron leaf baits were more sensitive than pears for detection of sporangia (Table 2 ). Pear baits were never effective at detection of broadcast sporangia and rarely facilitated detection of sporangia in intimate association with the fruit. Using rhododendron leaves, we detected sporangia between 75 and $100 \%$ of the time, whether broadcast or in intimate association with the leaf.

Seasonal distribution. $P$. ramorum was consistently recovered from soils and litter during the winter rainy season, and persisted in soil through July in 2004 and September in 2005 (Fig. 1A and B). Corresponding to pathogen recovery in the soil through the summer of 2005, spring rainfall events extended into June of 2005 (Fig. 1C), promoting late spring sporulation events (J. M. Davidson, unpublished data). P. ramorum recovery frequency from soil during the 2005 season was approximately three times higher than recovery in 2004 (Fig. 1A). Recovery frequency was greatest under bay laurel, followed by tanoak, with occasional recovery under redwood. Pathogen recovery in the leaf litter layer was generally less than in soil and persistence was limited to a shorter time period, with litter populations undetectable by late summer.

Summer pathogen survival. Soil moisture contents were different across the host-soil associations, with redwood soils having a higher soil moisture content than either bay laurel or tanoak soils in 2004 and 2005 ( $P \leq 0.01)$ (Fig. 2A and B). During both summer seasons, pathogen recovery was similar in the three host-associated soils; however, recovery varied across vertical locations of the leaf disks, with enhanced recovery observed in those incubated in soil ( $P \leq 0.0001)$ (Fig. 3A and B). In general, survival in all treatments was higher in 2005 than in 2004. Inoculum at the leaf litter surface exhibited $<10 \%$ recovery 1 week after deployment (Fig. 3A and B), and in 2005 approximately 3\% recovery was observed at the litter surface 1 day prior to the onset of the fall rains (Fig. 3B). Inoculum incubated at the interface of

TABLE 1. Soil organic matter content and $\mathrm{pH}$ associated with tagged bay laurel, tanoak, and redwood trees ${ }^{\mathrm{v}}$

\begin{tabular}{lcc}
\hline Soil association & \\
\hline Bay laurel & \% Organic matter & Average $\mathrm{pH}^{\mathrm{y}}$ \\
Tanoak & $13.7 \mathrm{a}^{\mathrm{z}}$ & $5.93 \mathrm{a}^{\mathrm{z}}$ \\
Redwood & $9.5 \mathrm{a}$ & $5.62 \mathrm{~b}$ \\
\hline
\end{tabular}

${ }^{\mathrm{v}}$ Fifteen trees each of bay laurel, tanoak, and redwood were tagged for repetitive soil sampling over time.

${ }^{\mathrm{w}}$ Soil samples were collected within a $1.5 \mathrm{~m}$ radius of tagged trees.

${ }^{x}$ Soils were collected in July 2004, air dried, passed through a $2 \mathrm{~mm}$ sieve, and organic matter content was determined with the Walkley-Black method (33). Values represent the average of 15 samples of each species.

${ }^{y} \mathrm{pH}$ was determined in a $0.01 \mathrm{M} \mathrm{CaCl}_{2}$ solution. Samples were collected monthly from April 2004 through November 2004. Values represent average $\mathrm{pH}$ of soils associated with 15 tagged trees of each species over time.

${ }^{\mathrm{z}}$ Different letters within columns represent significant differences based on the Waller-Duncan $K$ ratio test $(K=100)$. litter and soil exhibited similar survival as that incubated in soils over the first 8 weeks, but interface recovery dropped drastically between the 8 week sample time and the onset of fall rains in October. Recovery was $>60 \%$ in soil-incubated leaf disks at the close of the 2004 and 2005 summer seasons (Fig. 3A and B). Pathogen recovery was often observed in decomposing tissue, generally in residual vascular tissue.

Hydration of leaf disks enhanced pathogen recovery at every collection time (Table 3). Leaf disks incubated at the litter surface that were negative in the first assays were rarely rendered $P$. ramorum-positive after hydration. Because hydration-stimulated pathogen recovery was so dramatic at subsurface locations, the separation of means of percent recovery was impacted by posthydration data; therefore, Figure 3 illustrates total (or post-hydration) pathogen recovery, and Table 3 depicts the change in recovery contributed by hydration. Chlamydospore germination was occasionally observed in post-hydration-positive leaf disks after tissue was cleared in $\mathrm{KOH}$.

$P$. ramorum was baited from the bulk soil within cylindrical barriers throughout the entire summer season (Table 4). Conversely, recovery from outside the cylinders was minimal throughout the 2004 season, but $>20 \%$ over the first 8 weeks of 2005 (Table 4).

Chlamydospore production. Chlamydospore production was observed in cleared leaf disk tissue from all treatments. In 2004, chlamydospore production was significantly higher in soil-incubated leaf disks than in those incubated at the interface or the surface $(P \leq 0.0001)$ (Fig. 4A). In 2005, there was a significant interaction between host association of soil and vertical location of inoculum $(P \leq 0.001)$, but the general trend was similar to the 2004 data with higher spore production in soils than at the interface or surface (Fig. 4B). In both seasons, no significant difference in chlamydospore production was observed in prehydration-positive versus prehydration negative leaf disks, suggesting that differences in initial recovery were not related to mere differences in extent of colonization by $P$. ramorum. When posthydration negatives were paired with post-hydration positive leaf disks within a sachet, there were significantly more chlamydospores in disks that exhibited hydration-stimulated recovery than those nonresponsive to hydration $(t \leq 0.05)$.

Effect of soil drying. Soil type had no effect on pathogen recovery over time, but did influence chlamydospore production.

TABLE 2. Percent recovery ${ }^{v}$ of Phytophthora ramorum from sporangiainfested $^{\mathrm{w}}$ soils using rhododendron leaves and pears as baits ${ }^{\mathrm{x}}$

\begin{tabular}{lcc}
\hline Infestation treatment & Pear & Rhododendron \\
\hline${\text { Run } 1^{\mathrm{y}}}^{\text {Uninfested }} \mathrm{z}$ & 0 & 0 \\
Broadcast $_{\text {Intimate }}$ & 0 & 100 \\
Run 2 & 25 & 100 \\
Uninfested & 0 & \\
Broadcast & 0 & 0 \\
Intimate & 0 & 75 \\
Run 3 & & 75 \\
Uninfested & 0 & 0 \\
Broadcast & 0 & 75 \\
Intimate & 25 & 100 \\
\hline
\end{tabular}

${ }^{v}$ Percent recovery was based on number of positive isolations out of four replicate baits per treatment.

${ }^{\mathrm{w}}$ Sporangia were produced on $1 / 3$ strength V8 agar plugs incubated for $48 \mathrm{~h}$ in soil water. Sporangia were enumerated with a hemacytometer and then embedded on moist filter paper strips before introduction to soil.

${ }^{x}$ Baits were incubated in saturated soil for 2 days prior to isolation.

y The experiment was run three times to account for potential differences in pear quality throughout the year.

${ }^{\mathrm{z}}$ Inoculum was introduced either in intimate association with the bait or broadcast in the soil. Spore-embedded filter paper strips were adhered to the abaxial and adaxial surfaces of rhododendron leaves and to opposing sides of pear fruits. Uninfested filter papers were utilized as controls. 
Leaf disks incubated in redwood soils exhibited $40 \%$ fewer chlamydospores than those incubated in the bay laurel-associated soils $(P \leq 0.05)$. The influence of soil drying on pathogen recovery was different in the two experimental runs due to overall lower pathogen recovery in run 2 (Fig. 5). In comparison to inoculum maintained at $0.9 \mathrm{kPa} \Psi_{\mathrm{m}}$, soil drying reduced pathogen recovery by 100 and $64 \%$ after 24 weeks of incubation in runs 1 and 2, respectively $(P \leq 0.05)$ (Fig. 5). In these disturbed soils,
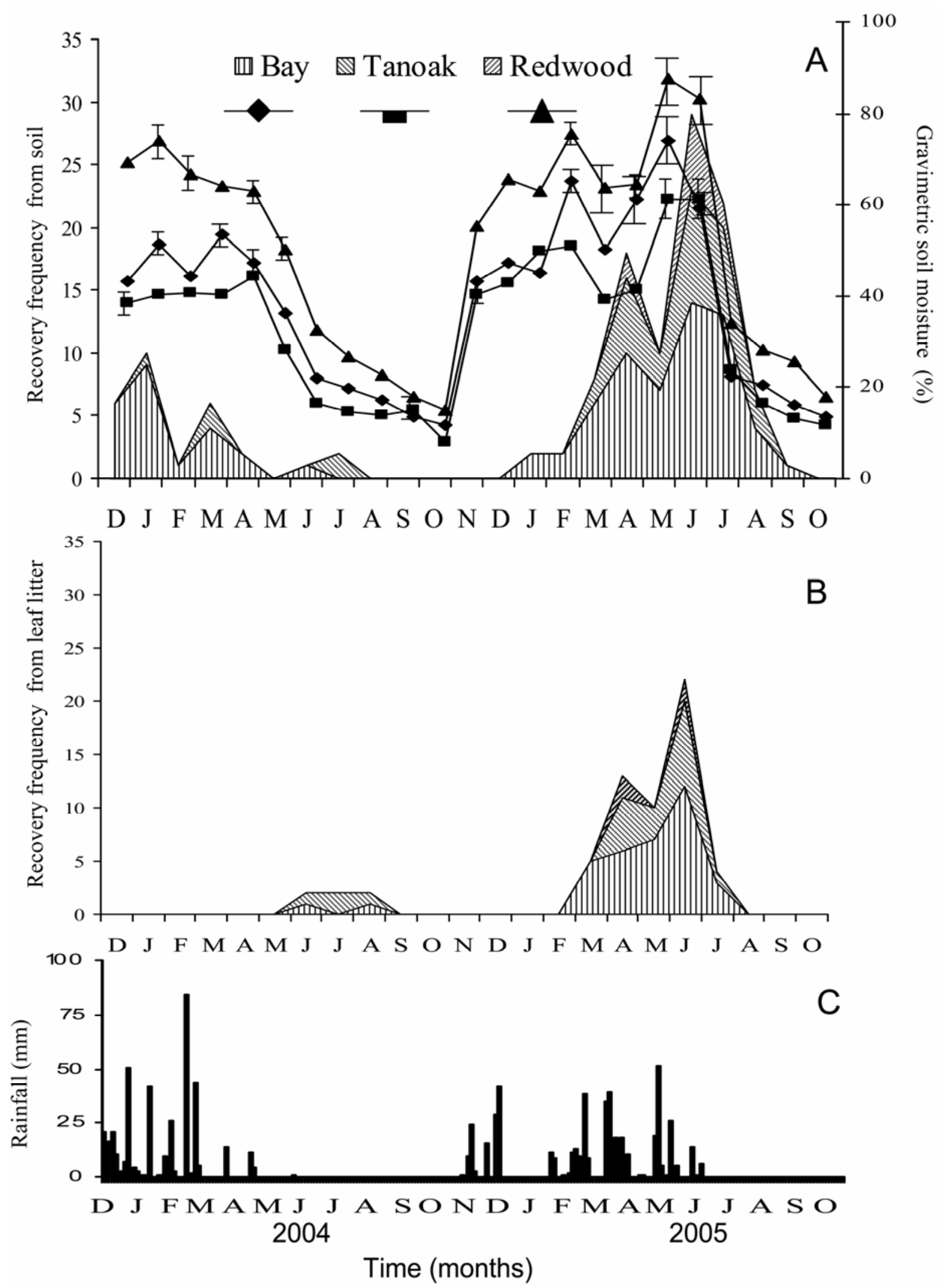

Fig. 1. The distribution of Phytophthora ramorum in soil and leaf litter in association with bay laurel, tanoak, and redwood was assessed monthly. A and B represent recovery from soil and leaf litter, respectively, with recovery frequency associated with each species $(n=15)$ stacked for a cumulative potential frequency of 45. Average soil moisture content $(n=10)$ corresponding with each collection time is included as a line graph in A. Error bars are inserted for points with a standard error $\geq 2.0$. C represents the daily rainfall recorded at Jack London State Park. 
soil moisture content did not vary significantly between the redwood soil and the bay laurel soil; therefore, soil moisture was averaged between soil types. Differences in soil moisture content upon drying were evident at weeks 8 and 24, where dry treatments exhibited up to $75 \%$ less gravimetric water than moist treatments (Fig. 5).

\section{DISCUSSION}

The variation of soil characteristics and host distribution over short distances within a forest may impact the disease cycle of SOD in natural systems. For example, soils associated with redwoods tended to have high organic matter content, enhancing soil moisture retention. The redwood-associated soils may promote pathogen survival in exceptionally dry summers based on the general trend that most Phytophthora spp. lose viability upon the advent of drying conditions (42). Our investigation of the natural distribution of inoculum within a redwood-tanoak forest illu- strates that $P$. ramorum was recovered more frequently under the bay laurel and tanoak hosts than under redwoods, suggesting that soil inoculum may originate from aerial sporulation on these hosts $(9,38)$. Soil samples were collected at a $1.5 \mathrm{~m}$ radius from tagged trees based on the steep dispersal gradient observed in soil inoculum of $P$. cactorum under infected apple trees (18). However, inoculum of $P$. ramorum may be dispersed greater distances in windblown rain (9), resulting in pathogen presence in soils associated with nonhost species or nonsporulating hosts. In this study, trees were selected to maximize distance from dissimilar overstory species and thereby reduce the potential drift of inoculum from neighboring sources.

Soil populations of $P$. ramorum dropped after the conclusion of the rainy season. As illustrated by the seasonal distribution data, soil populations of $P$. ramorum were higher in 2005 than in 2004, presumably due to the latter year's late spring rains in May and June (Fig. 1C). In a comparable study in Nigeria, cocoa plantation sites exposed to seasons with low rainfall and severe soil drying
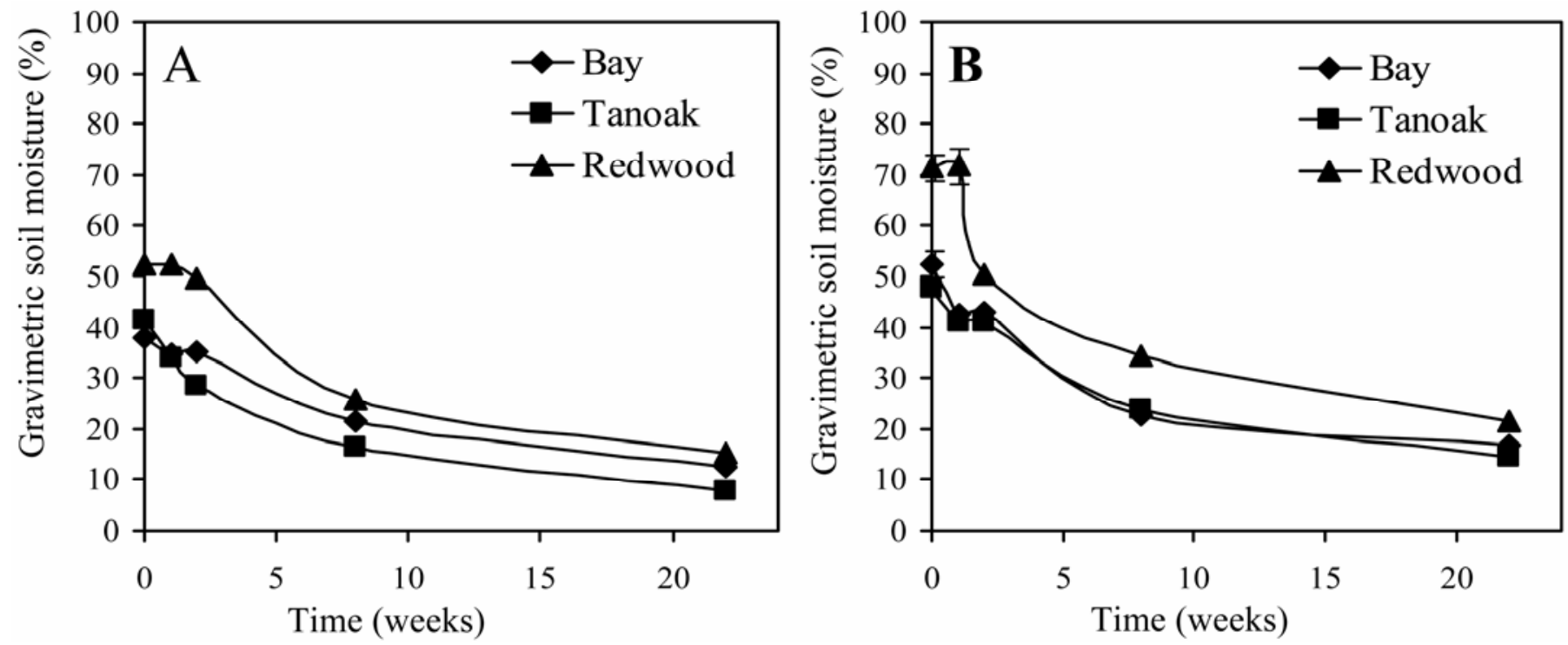

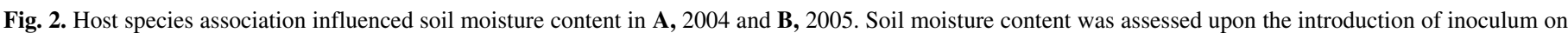

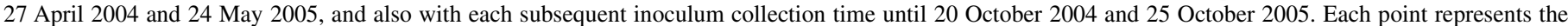
average soil moisture content $(n=10)$. Error bars were inserted at each point with a standard error $\geq 4.0$.
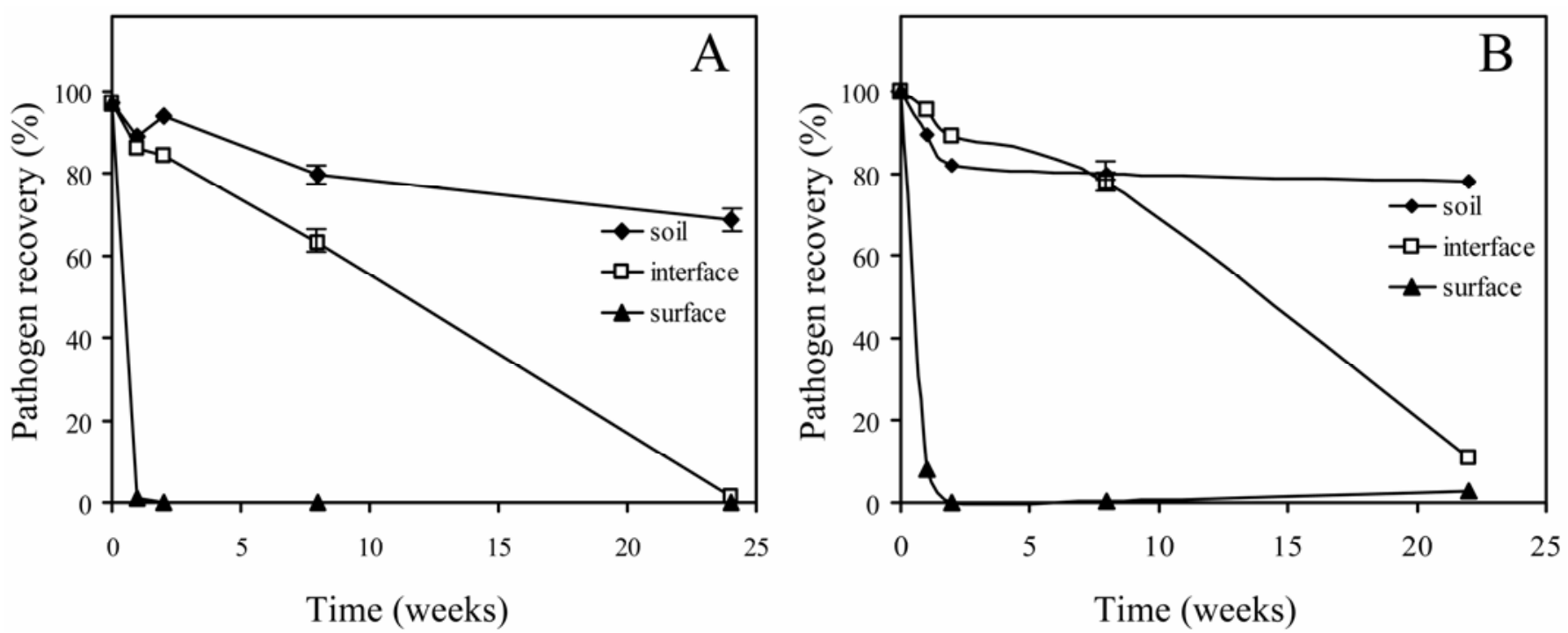

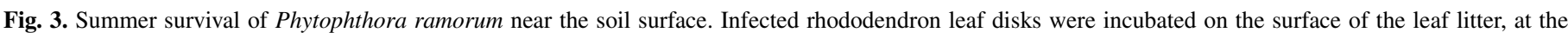

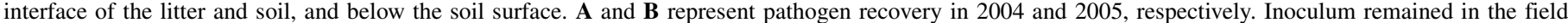

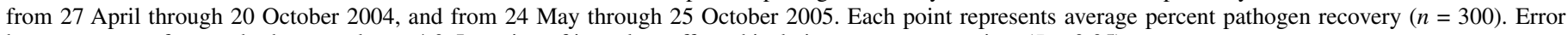
bars are present for standard error values $\geq 4$.0. Location of inoculum affected isolation recovery over time $(P \leq 0.05)$. 
exhibited low recovery of $P$. palmivora from soil (44). Davidson et al. $(7,9)$ documented that $P$. ramorum was not detected in soils associated with oaks within approximately 1 month of the last spring rain event. In contrast, $P$. ramorum was recovered from

TABLE 3. Percent change in Phytophthora ramorum recovery from leaf disks after a 3-week incubation in deionized water

\begin{tabular}{lccccc}
\hline Location & 1 week & 2 weeks & 8 weeks & 22 weeks & 24 weeks \\
\hline $2004^{\mathrm{x}}$ & & & & & \\
$\quad$ Soil & $\ldots$ & $\ldots$ & $3.0^{\mathrm{z}}$ & $\ldots$ & 3.7 \\
Interface & $\ldots$ & $\ldots$ & 10.0 & $\ldots$ & 1.0 \\
Surface & $\ldots$ & $\ldots$ & 0.0 & $\ldots$ & 0.0 \\
2005 & & & & & \\
Soil & 6.7 & 10.0 & 1.0 & 3.1 & $\ldots$ \\
Interface & 1.4 & 4.0 & 0.7 & 0.7 & $\ldots$ \\
Surface & 0.7 & 2.0 & 0.0 & 0.0 & $\ldots$ \\
\hline
\end{tabular}

${ }^{\mathrm{x}}$ In 2004, post-hydration recovery data was recorded on inoculum incubated in the field for 8 and 24 weeks. In 2005, post-hydration recovery was assessed at every sample time.

y Ten infected leaf disks were placed in each of 360 sachets and distributed under 30 trees at either of three vertical locations: below the soil surface, at the interface of the soil and litter, and at the litter surface. At each of four sample times, infected leaf disks $(n=300)$ were assessed from each vertical location to determine pathogen recovery.

${ }^{\mathrm{z}}$ The change in pathogen recovery contributed by hydration was determined by removing $P$. ramorum-negative leaf disk tissue from PARPH, incubating the leaf disks in deionized water for three weeks and then resubmerging the tissue in PARPH.

TABLE 4. Percent recovery of Phytophthora ramorum inside and outside cylinders ${ }^{y}$

\begin{tabular}{lccccc}
\hline Sample location & 1 week & 2 weeks & 8 weeks & 22 weeks & 24 weeks $^{\mathrm{z}}$ \\
\hline 2004 & & & & & \\
Inside cylinder & 33 & 16.6 & 20 & $\ldots$ & 20 \\
Outside cylinder & 3.3 & 0.0 & 0 & $\ldots$ & 0 \\
2005 & & & & & \\
Inside cylinder & 63.3 & 86.6 & 46.6 & 23.3 & $\ldots$ \\
Outside cylinder & 56.6 & 46.6 & 20 & 0.0 & $\ldots$
\end{tabular}

y Soil samples were collected both inside and outside each cylinder, and then baited with rhododendron leaves for determination of presence of P. ramorum. Values represent the percent of samples positive for the pathogen at each sample time $(n=30)$.

${ }^{z}$ Soil samples were collected concurrent with leaf disk inoculum 1,2,8, and 24 weeks after inoculum deployment in 2004 and after 1, 2, 8, and 22 weeks in 2005 . soils at JLSP up to 3 months after the last rain event. Multiple factors may contribute to the difference in detection and persistence of soil inoculum in these two systems. Davidson et al. $(7,9)$ monitored soil inoculum in a mixed-evergreen forest, whereas the present study was conducted in a redwood-tanoak forest. Though the two experimental sites are in close geographic proximity, the redwood-tanoak forest may have a higher inoculum load than the mixed-evergreen forest. Furthermore, the former study utilized pear baits, whereas rhododendron leaves may be more sensitive for detection of sporangia of $P$. ramorum.

Though rhododendron leaves were preferable to pears for baiting $P$. ramorum from soil, their application is limited due to the inability of the bait to detect chlamydospores. Consequently, we may presume that baits detected sporangia in soil for up to 3 months after the last spring rain event, but the potential for long-term chlamydospore survival is yet unknown. For routine baiting, however, rhododendron leaves are more cost effective and produce less bulk biohazard waste than pears. Additionally, enhanced pathogen colonization of rhododendron leaf baits may be achieved by incubating the tissue an additional 2 days in moist chambers, whereas pear baits were often rotting upon removal from saturated soil.

Given that some Phytophthora spp. may survive years in soil, even in the absence of a living host $(43,47)$, the summer survival potential of $P$. ramorum in forest soil was addressed. $P$. ramorum was demonstrated to survive in soils over the course of the hot, dry summers typical of the Mediterranean climate of CA coastal forests. Enhanced survival was observed in leaf disks incubated in soil, with marginal survival observed at the interface of litter and soil, suggesting that natural pedoturbation processes resulting in inoculum burial may promote long-term pathogen survival. Similarly, $P$. cactorum exhibited better survival in soil than at the soil surface in New York State apple orchards (18). In the P. ramorum system, the litter layer tends to prolong survival of underlying inoculum, perhaps by reducing exposure to drying. In a jarrah forest soil, the incorporation of leaf litter has been shown to induce hyphal lysis of P. cinnamomi (34), and leaf litter was also antagonistic to hyphal survival of $P$. palmivora in in vitro assays (25). Additionally, in a cocoa orchard, the litter layer supplies a natural barrier to rainsplashed inoculum originating from soil (24). Davidson et. al. (9) demonstrated, however, that bay laurel leaf litter may serve as an intermediary between soil inoculum and aerial infections by $P$. ramorum, and the results of this

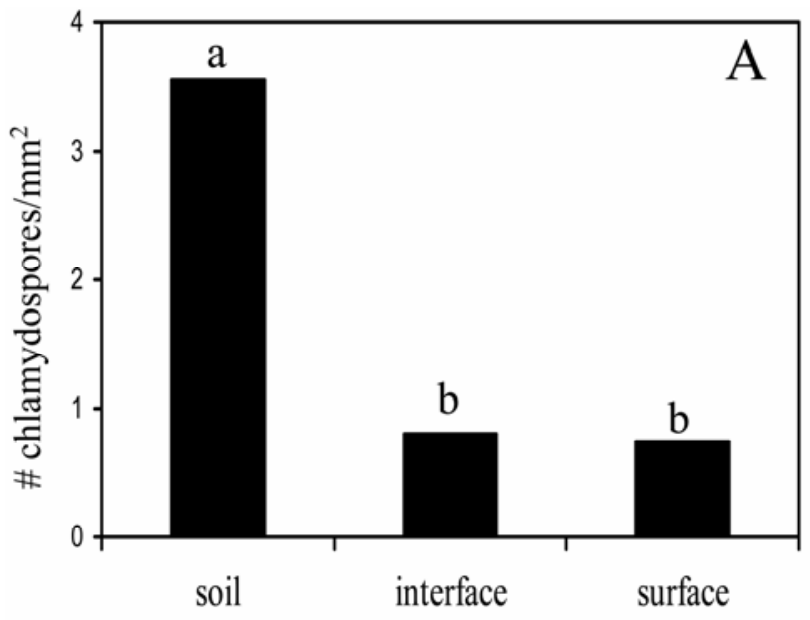

Vertical location

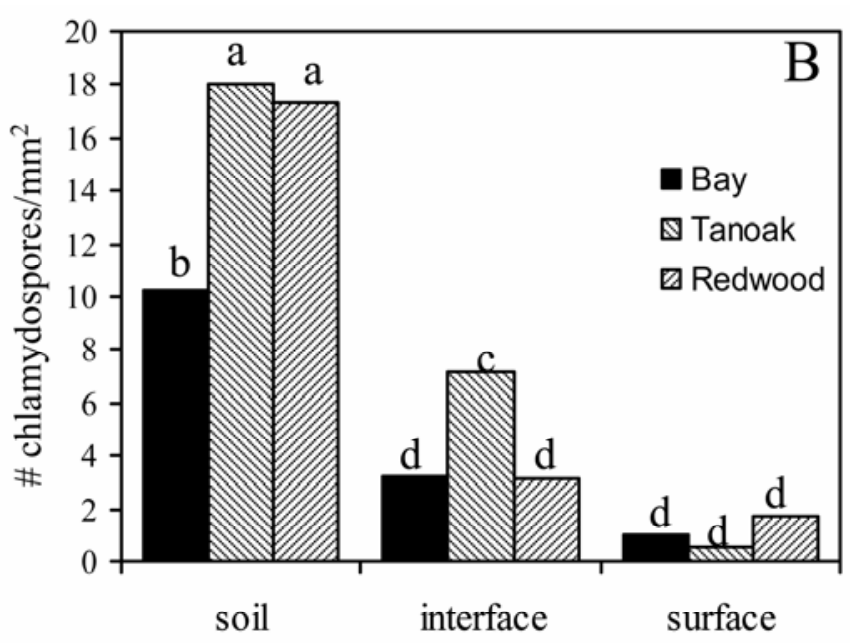

Vertical location

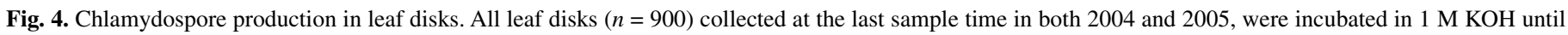

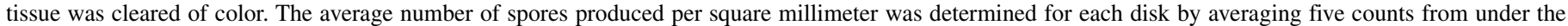

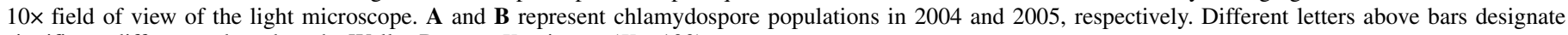
significant differences based on the Waller-Duncan $K$ ratio test $(K=100)$. 
survival study suggest that the pathogen may survive below the litter layer and contribute to the SOD disease cycle.

Hydration of $P$. ramorum-negative leaf disks with deionized water enhanced recovery of the pathogen. This technique was employed because repetitive rinsing of $P$. cinnamomi-infected tissue promoted the detection of false negatives, often aiding in pathogen recovery from asymptomatic tissue (19). The potential detection of survival structures upon hydration is hypothesized in the $P$. cinnamomi system (19). Chlamydospores of $P$. ramorum were more populous in tissues responding to hydration than in those not stimulated by hydration, suggesting a potential role of chlamydospores in hydration-stimulated pathogen recovery. Additionally, the hydrated tissues (prehydration negative) had similar chlamydospore counts than the nonhydrated tissues (prehydration positive), suggesting that the difference in initial pathogen recovery was not due to disparity of tissue colonization by the pathogen. Chlamydospore survival was evident from the accounts of spore germination in the cleared leaf disks; however, it is impossible to elaborate or extrapolate on dormancy, survival, and germination of these spores from observation of individual germination events.

Chlamydospore production by $P$. ramorum was high in soil, but the potential role of these structures in pathogen survival and persistence is unknown. Chlamydospores play a role in long-term survival of $P$. cinnamomi in soils, persisting up to 6 years in the absence of a host $(32,47)$. Conversely, $P$. palmivora and $P$. megakarya do not produce chlamydospores in cocoa orchard soils (44), but $P$. palmivora has been shown to produce chlamydospores under laboratory conditions $(22,34)$. The role of chlamydospores in the SOD disease cycle is yet unknown.

The high frequency of recovery of $P$. ramorum from soil within cylinders suggests that inoculum is easily transferred to the bulk soil from infected tissue. Consequently, the introduction of infected leaf disks to the forest created numerous "hot spots" of infestation within this already heavily infested site. Soil populations of both $P$. cactorum and $P$. palmivora have been linked to incorporation of infected tissue from aerial plant parts into soil
$(18,44)$. For example, the introduction of inoculated leaves to soil in microplots resulted in soil populations of P. cactorum $240 \%$ higher than bare soil control plots (18). In cocoa plantations, above-ground sanitation resulted in reduced populations of $P$. palmivora in soil (44). While sanitation is an effective disease management strategy in perennial crops, inoculum management strategies are limited within natural systems, relying mainly on reducing activities conducive to the movement of inoculum.

Similar to other Phytophthora spp. (42), P. ramorum loses viability upon soil drying. Because of the impracticality of maintaining a set of moist in situ field soils over the summer, a controlled experiment was designed by modifying a procedure designed for assessment of $P$. cinnamomi survival upon drying (5). After 6 months in drying soil, $P$. ramorum recovery drastically decreased regardless of the soil type. Though soil type did not influence survival, redwood soils were suppressive to chlamydospore production of $P$. ramorum, suggesting a limited production of survival structures in these soils. Suppression of $P$. cinnamomi has been observed in soils high in organic matter with complex and active microbial activity (17). Chlamydospores of $P$. cinnamomi were formed in soils both suppressive and conducive to avocado root rot, and disease suppressive soil had higher populations of bacteria and actinomycetes than conducive soils (3). The mechanism of suppression of $P$. ramorum chlamydospore production is unknown, but further studies will address this phenomenon under moist field conditions.

Multiple Phytophthora spp. cause root and crown rot of oaks in landscape and ornamental plantings (31), with the recently discovered $P$. quercina specifically associated with necrotic fine oak roots (21). Because the few reports of $P$. ramorum on roots involve isolation from asymptomatic tissue $(2,26,35)$, it is possible that $P$. ramorum has a yet undetected persistence or presence in roots. Both $P$. palmivora and $P$. cactorum are considered aerial pathogens, but both are infrequently isolated from roots of cocoa and apple, respectively, even in asymptomatic plants $(18,44)$. Consequently, determination of $P$. ramorum infection frequency and distribution in forest root tissues may pose a challenge due to
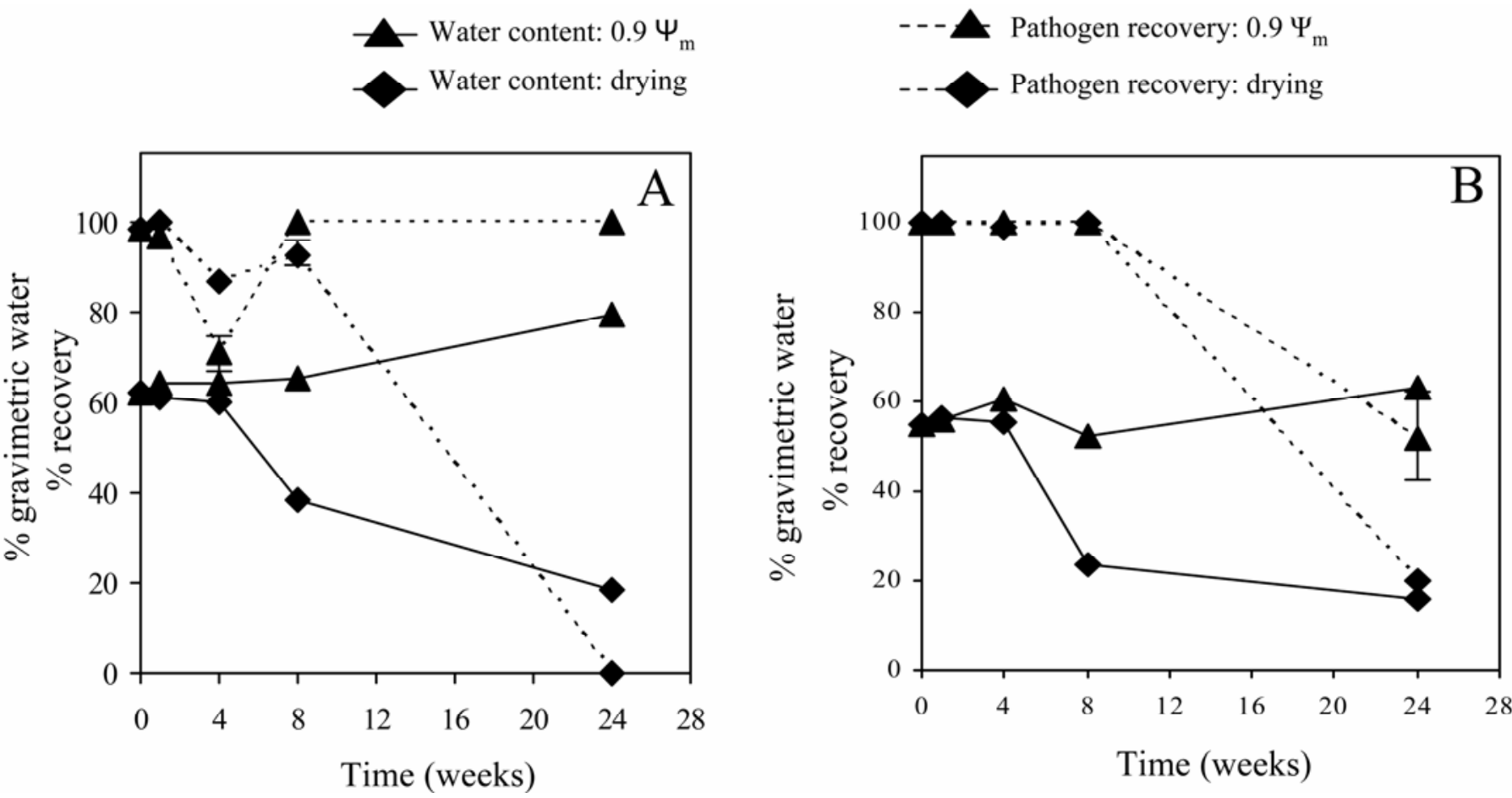

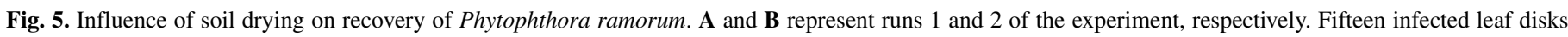

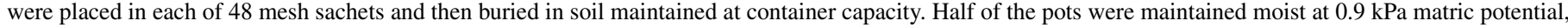

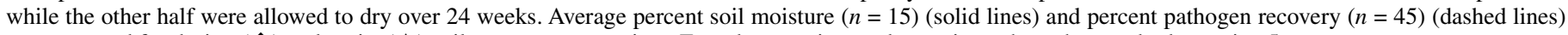
are portrayed for drying $(\boldsymbol{\Delta})$ and moist $(\boldsymbol{\Delta})$ soil treatments over time. Error bars are inserted on points where the standard error is $\geq 5$. 
the logistics of field sampling, potential for asymptomatic infections, and the identification of roots within heterogeneous plant populations. Infested soil or infected roots may provide hidden pathways for pathogen dispersal, evading detection and thwarting quarantine efforts.

Forest soils may act as inoculum reservoirs for $P$. ramorum within the SOD disease cycle, supporting both pathogen survival and chlamydospore production. The survival potential of $P$. $\mathrm{ra}$ morum in soil, combined with the recent reports of root infection $(2,26,35,39)$ highlight the importance for enhanced understanding of the dynamic interaction between soil inoculum and the soil chemical, physical, and microbial environment. Further investigation is needed to specifically address the detection and survival of chlamydospores in forest soils, the infection potential of these spores, and to elucidate the frequency and distribution of root infections within infested forests. Furthermore, the potential for soil-mediated suppression of chlamydospore production is an intriguing phenomenon worthy of investigation under moist field conditions.

\section{ACKNOWLEDGMENTS}

We thank H. Patterson, K. Falk, and J. Bienapfl for field and laboratory assistance; J. Parke, P. Maloney, and J. Davidson for insight and procedural suggestions; and S. Frankel and R. Cobb, as well as two anonymous reviewers for comments. The California State Parks, and specifically the staff at Jack London State Park were integral in allowing this research at their site. This research was funded by the USDA Forest Service Pacific Southwest Research Station, the Gordon and Betty Moore Foundation, and the American Philosophical Society.

\section{LITERATURE CITED}

1. APHIS. Pest Detection and Management Programs: Program Update Sudden Oak Death Jan. 10, 2005. http://www.aphis.usda.gov/ppq/ispm/ sod/updates/update 1-10-05.pdf

2. Bienapfl, J., Zanzot, J., Murphy, S., Garbelotto, M., and Rizzo, D. 2005. Isolation of a new lineage of Phytophthora ramorum from asymptomatic stems and roots of a commercial lot of rhododendron in California. (Abstr.) Phytopathology 95(suppl.):S9.

3. Broadbent, P., and Baker, K. F. 1974. Behaviour of Phytophthora cinnamomi in soils suppressive and conducive to root rot. Aust. J. Agric. Res. 25:121-137.

4. California Soil Resource Lab. Published online by the University of California-Davis, CA. http://casoilresource.lawr.ucdavis.edu/drupal/

5. Collins, S., Shearer, B., McComb, J., Colquhoun, I., and Hardy, G. 2002. Survival of Phytophthora cinnamomi in plant material under different soil and moisture conditions. Pages 154-158 in: Proceedings of the 'Phytophthora in Forests and Natural Ecosystems' 2nd International IUFRO Working Party, Albany, W. Australia.

6. Davidson, J. M., Fichtner, E. J., Patterson, H. A., Falk, K. R., and Rizzo, D. M. 2005. Mechanisms underlying differences in inoculum production by Phytophthora ramorum in mixed-evergreen versus tanoak-redwood forest in California. Page 500 in: Proceedings of the Sudden Oak Death Second Science Symposium: The State of our Knowledge. Pacific Southwest Research Station Gen. Tech. Rep. PSW-GTR-196.

7. Davidson, J. M., Rizzo, D. M., Garbelotto, M., Tjosvold, S., and Slaughter, G. W. 2002. Phytophthora ramorum and sudden oak death in California: II. Transmission and survival. USDA Forest Service Gen. Tech. Rep. PSW-GTR-184.

8. Davidson, J. M., Werres, S., Garbelotto, M., Hansen, E. M., and Rizzo, D. M. 2003. Sudden oak death and associated diseases caused by Phytophthora ramorum. Online. Plant Health Progress doi:10.1094/PHP-20030707-01-DG.

9. Davidson, J. M., Wickland, A. C., Patterson, H. A., Falk, K. R., and Rizzo, D. M. 2005. Transmission of Phytophthora ramorum in mixedevergreen forest in California. Phytopathology 95:587-696.

10. Erwin, D. C., and Ribeiro, O. K. 1996. Phytophthora Diseases Worldwide. American Phytopathological Society, St. Paul, MN.

11. Garbelotto, M., Davidson, J. M., Ivors, K., Maloney, P. E., Hüberli, D., and Rizzo, D. M. 2003. Non-oak native plants are the main hosts for the sudden oak death pathogen in California. Calif. Agric. 57:18-23.

12. Goheen, E. M., Hansen, E. M., Kanaskie, A., McWilliams, M. G., Osterbauer, N., and Sutton, W. 2002. Eradication of sudden oak death in Oregon. (Abstr.) Phytopathology 92(suppl.):S30.
13. Goheen, E. M., Hansen, E. M., Kanaskie, A., McWilliams, M. G., Osterbauer, N., and Sutton, W. 2002. Eradication of sudden oak death in Oregon. Plant Dis. 86:441.

14. Hansen, E. M., Reeser, P. W., Sutton, W., Winton, L., and Osterbauer, N. 2003. First report of A1 mating type of Phytophthora ramorum in North America. Plant Dis. 87:1267.

15. Hemmes, D. E., and Wong, L. D. S. 1975. Ultrastructure of chlamydospores of Phytophthora cinnamomi during development and germination. Can. J. Bot. 53:2945-1957.

16. Hemmes, D. E. 1983. Cytology of Phytophthora. Pages 9-40 in: Phytophthora: Its Biology, Taxonomy, Ecology and Pathology. D. C. Erwin, S. Bartnicki-Garcia, and P. H. Tsao, eds. American Phytopathological Society, St. Paul, MN.

17. Hoitink, H. A. J., and Boehm, M. J. 1999. Control within the context of soil microbial communities: A substrate-dependent phenomenon. Annu. Rev. Phytopathol. 37:427-446.

18. Horner, I. J., and Wilcox, W. F. 1996. Spatial distribution of Phytophthora cactorum in New York apple orchard soils. Phytopathology 86:1122-1132.

19. Hüberli, D., Tommerup, I. C., and Hardy, G. E., St. J. 2000. Falsenegative isolations or absence of lesions may cause mis-diagnosis of diseased plants infected with Phytophthora cinnamomi. Aust. Plant Pathol. 29:164-169.

20. Ivors, K. L., Hayden, K. J., Bonants, P. J. M., Rizzo, D. M., and Garbelotto, M. 2004. AFLP and phylogenetic analyses of North American and European populations of Phytophthora ramorum. Mycol. Res. 108:378-392.

21. Jung, T., Cooke, D. E. L., Blaschke, H., Duncan, J. M., and Osswald, W. 1999. Phytophthora quercina sp. Nov., causing root rot of European oaks. Mycol. Res. 103:785-798.

22. Kadooka, J. Y., and Ko, W. H. 1973. Production of chlamydospores of Phytophthora palmivora in culture media. Phytopathology 63:559-562.

23. Kanaskie, A., Osterbauer, N., McWilliams, M. G., Goheen, E. M., Hansen, E. M., and Sutton, W. 2005. Eradication of Phytophthora ramorum from Oregon tanoak forests-status after three years. Proceedings of the 2nd Sudden Oak Death Science Symposium: The State of Our Knowledge. Pacific Southwest Research Station, Forest Service, USDA Rep. No. PSW-GTR-196.

24. Konam, J. K. 1992. The epidemiology of Phytophthora palmivora diseases of cocoa in Papua New Guinea. Ph.D. Thesis, University of Papua, New Guinea.

25. Konam, J. K., and Guest, D. I. 2002. Leaf litter mulch reduces the survival of Phytophthora palmivora under cocoa trees in Papua, New Guinea. Aust. Plant Pathol. 31:381-383.

26. Lewis, C. D., Roth, M. L., Choquette, C. J., and Parke, J. L. 2004. Root infection of rhododendron by Phytophthora ramorum. (Abstr.) Phytopathology 94(suppl.):S61.

27. Linderman, R. G., and Davis, E. A. 2006. Survival of Phytophthora ramorum campared to other species of Phytophthora in potting media components, compost, and soil. Hort. Technol. 16:502-506.

28. Maloney, P. E., Lynch, S. C., Kane, S. F., Jensen, C. E., and Rizzo, D. M. 2005. Establishment of an emerging generalist pathogen in redwood forest communities. J. Ecol. 93:899-905.

29. Masago, H., Yoshikawa, M., Fukada, M., and Nakanishi, N. 1977. Selective inhibition of Pythium spp. on a medium for direct isolation of Phytophthora spp. from soils and plants. Phytopathology 67:425-428.

30. McCarren, K. L., McComb, J. A., Shearer, B. L., and Hardy, G. E., St. J. 2005. The role of chlamydospores of Phytophthora cinnamomi-a review. Aust. Plant Pathol. 34:333-338.

31. Mircetich, S. M., Campbell, R. N., and Matheron, M. E. 1977. Phytophthora trunk canker of coast live oak and cork oak trees in California. Plant Dis. Rep. 61:66-70.

32. Mircetich, S. M., and Zentmyer, G. A. 1966. Production of oospores and chlamydospores of Phytophthora cinnamomi in roots and soil. Phytopathology 56:1076-1078.

33. Nelson, D. W., and Sommers, L. E. 1982. Total carbon, organic carbon and organic matter. Pages 539-579 in: Methods of Soil Analysis: Part 2. Chemical and Microbiological Properties. A. L. Page, ed. ASA Monograph Number 9.

34. Nesbitt, H. J., Malajczuk, N., and Glenn, A. R. 1979. Effect of organic matter on the survival of Phytophthora cinnamomi Rands in soil. Soil Biol. Biochem. 11:133-136.

35. Parke, J. L., Bienapfl, J., Oh, E., Rizzo, D., Hansen, E., Buckles, G., Lee, C., and Valachovic, Y. 2005. Natural infection of tanoak seedling roots by Phytophthora ramorum. (Abstr.) Phytopathology 96(suppl.):S90.

36. Rizzo, D. M., and Garbelotto, M. 2003. Sudden oak death: Endangering California and Oregon forest ecosystems. Frontiers Ecol. Environ. 1:197204.

37. Rizzo, D. M., Garbelotto, M., Davidson, J. M., Slaughter, G. W., and Koike, S. T. 2002. Phytophthora ramorum as the cause of extensive mortality of Quercus spp. and Lithocarpus densiflorus in California. Plant Dis. 86:205-214. 
38. Rizzo, D. M., Garbelotto, M., and Hansen, E. M. 2005. Phytophthora ramorum: Integrative research and management of an emerging pathogen in California and Oregon forests. Annu. Rev. Phytopathol. 43:309-335.

39. Shishkoff, N., and Senesac, A. 2005. Susceptibility of Phytophthora ramorum of roots and shoots of common container weeds. (Abstr.) Phytopathology 95(suppl.):S96.

40. Smiley, R. W., and Cook, R. J. 1972. Use and abuse of the soil pH measurement. Phytopathology 62:193-194.

41. Timmer, L. W., Sandler, J. H., Graham, J. H., and Zitko, S. E. 1988. Sampling citrus orchards in Florida to estimate populations of Phytophthora parasitica. Phytopathology 78:940-944.

42. Tsao, P. H. 1983. Factors affecting isolation and quantitation of Phytophthora from soil. Pages 219-236 in: Phytophthora: Its Biology, Taxonomy, Ecology, and Pathology. D. C. Erwin, S. Bartnicki-Garcia, and P. H. Tsao, eds. American Phytopathological Society, St. Paul, MN.
43. Turner, P. D. 1965. Behavior of Phytophthora palmivora in soil. Plant Dis. Rep. 49:135-137.

44. Ward, M. R., and Griffin, M. J. 1981. Soil phase of cacoa Phytophthora. Pages 50-61 in: Epidemiology of Phytophthora on Cocoa in NigeriaFinal Report of the International Cocoa Black Pod Research Project. P. H. Gregory and A. C. Maddison, eds. Commonwealth Mycological Institute, Kew, Surrey, England.

45. Werres, S., and de Merlier, D. 2003. First detection of Phytophthora ramorum mating type A2 in Europe. Plant Dis. 87:1266.

46. Werres, S., Marwitz, R., Man In't Veld, W. A., De Cock W. A. M. Bonants, P. J. M., De Weerdt, K., Ilieva, E., and Baayen, R. P. 2001. Phytophthora ramorum sp. Nov., a new pathogen on Rhododendron and Viburnum. Mycol. Res. 105:1155-1165.

47. Zentmyer, G. A., and Mircetich, S. M. 1966. Saprophytism and persistence in soil by Phytophthora cinnamomi. Phytopathology 56:710-712. 